\title{
Examining The Relationship Between Commitment And Airline Loyalty And The Moderating Effect Of Uncertainty Avoidance
}

\author{
Jirawat Anuwichanont, Ph.D., Suan Dusit Rajabhat University, Thailand
}

\begin{abstract}
Customer loyalty has long been of significant interest to both academic scholars and marketing practitioners. Considerable researches in marketing has long supported commitment as a major predictor of loyalty. Notwithstanding that the association between customers' commitment and loyalty is well documented, little understanding of how the multi-dimensions of commitment influence customer loyalty in the airline context. Thus, the impact of the multidimensional conceptualization of commitment (informational complexity, position involvement and volitional choice) on loyalty was investigated in the airline context. Besides commitment, the examinations of the influence of brand affect and brand trust on loyalty constructs were also included. Moreover, the moderating effect of uncertainty avoidance on the links between brand affect and brand trust and loyalty was also taken into account. The empirical findings supported the three dimensions of commitment as the determinants of loyalty. But no support was found for the hypothesized relationships between informational complexity and attitudinal loyalty and between volitional choice and attitudinal loyalty. As hypothesized, brand affect contributes to predicting both attitudinal and behavioral loyalty; while brand trust influences solely on behavioral loyalty. Contrary to expectations, no support was found for the moderating effect of uncertainty avoidance on the relationships between brand affect and brand trust and loyalty constructs.
\end{abstract}

Keywords: Commitment, Brand Affect, Brand Trust, Loyalty, Uncertainty Avoidance

\section{INTRODUCTION}

$n$ the past decade the airline industry has gone through a significant shift in its structure. Competition in
the airline business is fierce, particularly during the last ten years when the industry was in its worst
situation of terrorism, war, and epidemic diseases. Currently, this intense competition forces the whole industry to re-evaluate their service offering and customer loyalty programs. Thus, all airlines strive to develop loyalty among existing and new customers, while improving customer retention in an attempt to boost their profitability. Emphasis of this study is placed on examining customer loyalty towards airlines which will contribute to better understanding the process by which customers become loyal to airlines. Considerable empirical researches in marketing support the links between commitment and loyalty (e.g. Reichheld 1996; Zeithaml, Berry, and Parasuraman 1996). Most prior studies of commitment used the uni-dimensional conceptualization in examining the relationship with customer loyalty (Caceres and Paparoidamis, 2007; Watson, Hubbard and Wiese 2000). However, only a few studies examine the association between commitment and loyalty in the multi-dimensional perspective. Empirically, the meaning of commitment used in the marketing literature is more complex than its traditional conceptualization and should be extended to include three dimensions: (1) informational complexity, (2) position involvement and (3) volitional choice (Iwasaki and Havitz, 2004). The examination of the relationship between the multi-dimensional commitment and loyalty will provide marketing practitioners more insight of the directions to improve customer loyalty. Besides commitment, the influence of brand on loyalty has been acknowledged in explaining that individuals high in brand affect and trust have high tendency to stay loyal with 
their choices (Reichheld and Schefter, 2000). Nonetheless, less attention was paid to empirically examine the association between brand and loyalty in a service context especially the airline industry. Consequently, this study will be another extension of knowledge of customer loyalty in explaining commitment, brand affect and trust as essential precursors for the development of airline loyalty.

\section{RESEARCH OBJECTIVES}

The objectives of this research are as follows:

- $\quad$ to examine the relative effects of commitment dimensions on loyalty

- $\quad$ to examine the impact of brand affect and brand trust on loyalty

- to investigate the moderating effects of uncertainty avoidance on the link between commitment, brand affect, brand trust and loyalty.

\section{LITERATURE REVIEW AND HYPOTHESES DEVELOPMENT}

\section{Loyalty}

From a managerial point of view, customer loyalty has long been acknowledged as an underlying objective for strategic marketing planning since it brings about many favorable outcomes to companies. First, it is much less expensive to retain current visitors than it is to seek new ones (Reicheld and Sasser, 1990). Further, loyal customers are more likely to discuss past service experiences positively than non-loyal customers, creating a potential for word-of-mouth advertising at no extra cost to the service provider (Shoemaker and Lewis, 1999). Third, it secures the relationship between customer and service provider, when the customer is faced with increasingly attractive competitive offers, or the supplier's own shortcomings. Finally, loyal customers are more easily accessible than first-timers since organizations usually retain records, making targeted indirect marketing more feasible. This knowledge permits suppliers to precisely target the repeat segment and solicit direct responses to promotions (Reid and Reid, 1993).

Loyalty has been measured in the following ways: (1) the behavioral approach, (2) the attitudinal approach, and (3) the composite approach (Jacoby and Chestnut, 1978). The composite approach comprising an integration of both attitudinal and behavioral dimensions is extensively used in examining loyalty (e.g., Aaker 1991; Backman and Crompton, 1991; Assael, 1998; Oliver, 1999; Pritchard et al., 1999). In short, customer loyalty is regarded as an integration of behavioral measures (in the sense of exclusive purchase, hard-core loyalty, repeat purchase probability, share of category requirements, etc.) and attitude (with reference to brand preference, liking, commitment, intention-to-buy, etc.) (Uncles and Laurent, 1997)._Day (1969) argues that to be truly loyal, a consumer must both purchase the brand as well as have a positive attitude toward it. This composite approach seems to be the most comprehensive, it is not necessarily the most practical.

Like tourism, the measurement of loyalty in an airline context is quite difficult, since the purchase is a rare purchase (Oppermann, 1999). It does not occur on a continuous basis but rather infrequently (Jago and Shaw, 1998). It can also be covert behavior as reflected in intention to revisit in the future (Jones and Sasser, 1995). In addition, the process of repetitive purchase might be due to convenience, habits or no alternatives (Bei and Chiao, 2001). However, Hennig-Thurau and colleagues (2002) state that loyalty is more than a repetitive purchase but it is also related to appreciation and commitment. Empirical studies supported that loyal customers are most likely to publicize the company and its products through positive word of mouth and through a desire to maintain that relationship (Hennig-Thurau et al., 2002). Moreover, loyalty also refers to committed behavior that is manifested by propensity to participate in a particular recreation service and recommendation to others (Oppermann, 2000). Consistently, this notion is supported by Jones and Sasser (1995) who argued that intent to repurchase is a very strong indicator of future behavior. 


\section{Commitment and Loyalty}

Commitment has been defined in the context of cognitive consistency theories (Freedman, 1964), and has also been interpreted from a multi-dimensinal perspective (Pritchard et al., 1992). Most prior studies of commitment used the uni-dimensional conceptualization in examining the relationship with customer loyalty (Caceres and Paparoidamis, 2007). Empirically, the meaning of commitment used in the marketing literature is more complex than its traditional conceptualization and should be extended to include three dimensions: (1) informational complexity, (2) position involvement and (3) volitional choice (Iwasaki and Havitz, 2004). First, informational complexity is regarded as the extent to which individuals are motivated to seek informational complexity and consistency in the cognitive schema behind their preference. Second, position involvement is regarded as the extent to which individuals are willing to identify with important values and self-images that are associated with that preference. Finally, volitional choiable is regarded as the extent to which individuals are able to freely initiate choices that are meaningful (Iwasaki and Havitz, 2004; Pritchard, Havitz, and Howard, 1997). Repeat patronage is relatively meaningless if a participant has no real variety from which to choose.

Several researchers (e.g., Pritchard et.al., 1999; Chaudhuri and Holbrook, 2001) state that commitment, the most important attitudinal measure, is a significant indicator of loyalty, as it represents an emotional or psychological attachment to a brand within a product class. In addition, a degree of dispositional commitment in terms of some unique values associated with the brand is part of attitudinal brand loyalty (Chaudhuri and Holbrook, 2001). In the relationship context, commitment is considered as an enduring desire to maintain a valued relationship (Moorman, Zaltman and Deshpande, 1992). Gundlach, Achrol et al. (1995) viewed commitment as essential to a long-term, successful relationship. Brand commitment reduced uncertainty and saves a customer the cost of seeking new relational exchanges with other brands (Aaker, 1991). Hence, commitment underlies the ongoing process of continuing and maintaining a valued and important relationship. According to Samuelsen and Sandvik (1997), 'commitment' is considered as a bond between the customer and a particular brand that enhances the definition of loyalty by moving it beyond considerations of only simple repeat purchase of a brand. In light of the preceding discussion and findings we propose that:

H1a: Informational complexity will positively influence attitudinal loyalty.

H1b: Informational complexity will positively influence behavioral loyalty.

H2a: Position involvement will positively influence attitudinal loyalty.

H2b: Position involvement will positively influence behavioral loyalty.

H3a: Volitional choice will positively influence attitudinal loyalty.

H3b: Volitional choice will positively influence behavioral loyalty.

\section{Brand Affect and Loyalty}

Several researchers note that the important role of affect in brand loyalty (e.g., Gremler and Brown 1998; Dick and Basu 1994). The emphasis of both academic and managerial effort has focused on determining the predictors of customers' future intentions from the affective perspective (e.g., Chaudhuri and Holbrook, 2001; Garbarino and Johnson, 1999; Zeithaml et al., 1996; Oliva et al., 1992). The reason is that brand-loyal consumers may be willingly to pay more because they perceive a unique value in the brand that no alternative can provide (Reichheld 1996). This uniqueness may derive from more favorable affect when customers use the brand or from greater trust in the reliability of a brand. Thus, loyalty is created by trust in the brand and by feeling or affect elicited by the brand. In order for a consumer to develop a feeling of loyalty, it is required that he has a satisfying experience with the brand that develops into a positive attitude of affect and trust (Urban and Sultan. 2000).

Empirically, brand loyalty is related to positive affect and this may prevent the exploration of other alternatives in the short run, steady customer benefits are likely to accrue from such affective bonding in the long run (Gundlach, Achrol et al., 1995). Consistently, Dick and Basu (1994) proposed that brand loyalty was greater under conditions of more positive emotional mood or affect. Hence, brands that make customers "happy" or "joyful" or "affectionate" should prompt greater purchase and attitudinal loyalty. 
Chaudhuri and Holbrook (2001) defined brand affect as a brand's potential to elicit a positive emotional response in the average consumer as a result of its use. They also found that hedonic value in the product category is significantly and positively related to brand affect, whereas the utilitarian value of the product category was significantly but negatively related to brand affect. They also suggested that brand trust and brand affect are two separate constructs in driving brand loyalty. Several empirical studies have indicated that brand affect was crucial factors in driving brand loyalty (Dick and Basu, 1994; Assael, 1998; Garbarino and Johnson, 1999; Ringberg and Gupta, 2003). Thus, to retain customers and drive brand profitability, brand affect is regarded as an important factor of brand loyalty (Park and Srinivasan, 1994; Bello and Holbrook, 1995; Aaker, 1996). Based on the above discussion, the hypotheses are developed as follows:

H4a: Brand affect will positively influence attitudinal loyalty.

H4b: Brand affect will positively influence behavioral loyalty.

\section{Brand Trust and Loyalty}

Morgan and Hunt (1994) suggested the conceptual definition of trust as "a willingness to rely on an exchange partner in whom one has confidence". According to their conceptualization, trust is viewed as confidence in the performance, integrity, and reliability of the provider (Morgan and Hunt, 1994; Moorman, Zaltman and Deshpande, 1992). In consonance with Morgan and Hunt's definition, trust is further defined as the willingness of the average consumer to rely on the ability of the brand to perform its stated function (Chaudhuri and Holbrook, 2002) and as the confident expectations of the brand's reliability and intentions (Delgado, Munuera et al., 2003). In the relational exchanges, trust was defined as the expectations held by the consumer that the service provider is dependable and can be relied on to deliver on its promises (Sirdeshmukh, Singh et al., 2002).

Several conceptual and empirical studies have acknowledged customer trust as a key determinant of relational commitment (Tax, Brown et al., 1998; Garbarino and Johnson, 1999). In addition, trust was proposed as the most powerful relationship marketing tool in building strong customer relationships and sustainable market share (Urban, Sultan et al., 2000; Reichheld and Schefter, 2000; Berry, 1996). Empirically, considerable research findings indicated that the positive relationship existed between brand trust and brand loyalty, which in turn maintained the positive relationship with brand equity (Ballester and Munuera, 2005). Consistently, brand trust was found to directly relate to both purchase and attitudinal loyalty and indirectly relate to brand performance (market share and relative price) (Chaudhuri and Holbrook, 2001).

Recent studies have suggested a positive association between loyalty and trust, defined as containing elements such as honesty, competence, benevolence, reliability, and customer orientation (Chow and Holden 1997; Doney and Cannon, 1997; Morgan and Hunt, 1994; Sharma and Patterson, 1999). In general, trust is viewed as the determinant of relationship commitment and future purchase intentions in the context of buyer-seller relationships and business-to-business relationships (Morgan and Hunt, 1994; Moorman et al., 1992). In addition, trust has been found to be predictive of both purchase and attitudinal loyalty in the consumer market context (Chaudhuri and Holbrook, 2001). Based on the above discussion, we hypothesize that:

H5a: Brand trust will positively influence attitudinal loyalty.

H5b: Brand trust will positively influence behavioral loyalty.

\section{The Moderating Effects of Uncertainty Avoidance}

Nevertheless, a review of the empirical evidence so far shows that the vast of the studies were conducted in Western countries. Few studies were conducted in Asian countries, high in uncertainty avoidance, where the members of a culture resist in changes and worry about uncertain or unknown situations (Hofstede, 1991). Individuals high in uncertainty avoidance tend to have resistance to change, a preference for tasks with sure outcomes and known risks and a propensity to stay loyal with their choices (Hofstede 1991). Empirical evidence suggests that the effect of personal attitudes on purchase intentions is moderated by the degree of national culture (Lee and Green, 1991). Hence, this study will extend knowledge in this area through examining the extent to which orientation of uncertainty avoidance moderates the relationship between brand affect, brand trust and loyalty 
constructs of attitudinal and behavioral loyalty. As a consequence, we hypothesize that:

H6a,b: The higher the level of uncertainty avoidance, the greater is the likelihood that brand affect will lead to greater (a) attitudinal loyalty and (b) behavioral loyalty.

H7a,b: The higher the level of uncertainty avoidance, the greater is the likelihood that brand trust will lead to greater (a) attitudinal loyalty and (b) behavioral loyalty.

\section{RESEARCH METHODOLOGY}

Target populations are Thai travelers who have ever traveled with Thai Airways International. Derived from indefinite population formula for determining sample size, the calculated sample size for this study is 400 . The researcher team recruited for additional 100 sample as a buffer against invalid questionnaire. Consequently, total sample size for this study is 500. The purposive sampling method is employed to collect data from Thai travelers in Bangkok. The first draft of the questionnaire was subjected to pretesting with total respondents of 40 .

\section{Measures}

To measure commitment which comprises three dimensions (informational complexity, position involvement and volitional choice), we applied the nine-item 7-point Likert scale from Iwasaki and Havitz (2004). The composite reliability score was 0.75 exceeding the acceptable threshold of 0.70 . Brand affect was assessed using a three-item scale based on Chuadhuri and Holbrook (2001) with seven-point Likert rating scale. Similarly, brand trust was measured using a four-item scale adapted from previous studies by Chuadhuri and Holbrook (2001). The scale items of brand affect and brand trust show good internal reliability with high alpha coefficients at 0.92 and 0.81 respectively. Regarding loyalty, this study focuses on attitudinal and behavioral loyalty. With regards to attitudinal and behavioral loyalty, the eleven-item scale developed by Pritchard et al. (1999) were employed in this study. The loyalty scale demonstrated substantial internal consistency with reliability estimates of 0.91 in the previous study of Pritchard et al. (1999).

\section{RESULTS}

Total number of questionnaires distributed was 500, but only 474 questionnaires obtained were valid. It can be indicated that there is almost equal split in the gender of respondent ( $46 \%$ are male; $54 \%$ are female). $32 \%$ of them are 25-34 years old. Half of them are married. The majority of them achieves bachelor degree and come from administrative/ managerial level. The majority's monthly household income level is between 1,626 -2,000US\$.

The preliminary analysis revealed that the measurement scales of constructs (informational complexity, position involvement, volitional choice, brand affect, brand trust, attitudinal loyalty, behavioral loyalty and uncertainty avoidance) had acceptable internal consistency, which was evidenced by high Cronbach's alpha ranging from $0.76-0.96$ which exceeded the threshold value of 0.70 (Nunnally, 1978). Exploratory factor analysis (EFA) was conducted using principal component analysis on measurement scales of each construct and only one factor was extracted as expected, which explained approximately $71-87$ percent of the total variance respectively. The findings indicated that all constructs satisfied the criteria of unidimensionality and reliability.

Following EFA, confirmatory factor analysis using AMOS version 4.01 was undertaken for scale purification and assessing the psychometric properties of measures in terms of testing convergent validity and reliability properties of the measures. The analysis of exogenous construct measurement model revealed that factor loadings of informational complexity, position involvement, volitional choice, brand affect and brand trust were all significantly high ranging from 0.74 to 0.96 . Consistently, the analysis of endogenous construct measurement model also indicated that factor loadings of attitudinal loyalty, behavioral loyalty and uncertainty avoidance were all significantly high ranging from 0.87 to 0.94 . In sum, as evidence of convergent validity, all items loaded significantly on their prespecified latent constructs and all estimated loading exceed the critical value of 0.5 (Bagozzi and Yi, 1988). Moreover, t-values of the factor loadings were all statistically significant (t-value > 1.65) ranging from 9.26 to 26.33 for exogenous constructs and ranging from 20.13 to 31.60 for endogenous constructs, providing some support for convergent validity of the constructs (Anderson and Gerbing, 1988; Bollen, 1989). 
These findings indicated that all indicators were related significantly to the construct with low standardized residuals which satisfied the requirement of internal consistency and adequate fit of scale items as shown in Table 1. In addition, all measures of overall model fit for both measurement models were within the acceptable levels, indicating a sound fit of the data to the model.

Additionally, the assessment of internal consistency of the measurement scale was conducted through the examination of composite reliability and variance extracted measures for each construct. Composite reliability represents the shared variance among a set of observed variables that measure an underlying construct while variance extracted measures reflects the overall amount of variance in the indicators accounted for by the latent construct (Fornell and Larcker, 1981). The findings showed that all composite reliability of constructs exceeded the threshold level of 0.7 ranging from 0.85 to 0.96 , indicating high internal consistency of the measurement scales (Fornell and Larcker, 1981; Bagozzi and Yi, 1988; Hair et al., 1998). Finally, average variance extracted score for all constructs were close to and exceeded the recommended level of 0.5 ranging from 0.66 to 0.82 , indicating that a higher amount of variance in the indicators was captured by the construct compared to that accounted for by measurement error (Fornell and Larcker, 1981; Hair et al., 1998). The composite reliability and average variance extracted of each construct are summarized in Table1.

Table1: Summary of Measurement Model Results

\begin{tabular}{lcccc}
\hline \multicolumn{1}{c}{ Construct } & No. of items & Factor loading & $\begin{array}{c}\text { Composite reliability } \\
\text { coefficient }\end{array}$ & $\begin{array}{c}\text { Average variance } \\
\text { extracted }\end{array}$ \\
\hline Exogenous Construct Measurement Model & & & & \\
\hline Informational complexity & 2 & $0.85-0.88$ & 0.90 & 0.76 \\
\hline Position involvement & 3 & $0.68-0.96$ & 0.93 & 0.76 \\
\hline Volitional choice & 2 & $0.74-0.82$ & 0.85 & 0.66 \\
\hline Brand affect & 3 & $0.85-0.95$ & 0.93 & 0.82 \\
\hline Brand trust & 4 & $0.80-0.90$ & 0.92 & 0.73 \\
\hline
\end{tabular}

Model Goodness-of-fit statistics: Chi-square $=182.34$, Degrees of freedom $=63, \chi^{2} / \mathrm{df}=2.89, \mathrm{p}$ value $=0.000, \mathrm{GFI}=0.915$, AGFI $=0.859$, RMSR $=0.091, \mathrm{TLI}=0.948, \mathrm{CFI}=0.964, \mathrm{NFI}=0.947$ and $\mathrm{RMSEA}=0.083$

Endogenous Construct Measurement Model

\begin{tabular}{lllll}
\hline Attitudinal loyalty & 3 & $0.87-0.89$ & 0.91 & 0.78 \\
\hline Behavioral loyalty & 6 & $0.87-0.94$ & 0.96 & 0.79 \\
\hline Uncertainty avoidance & 6 & $0.80-0.89$ & 0.93 & 0.71 \\
\hline
\end{tabular}

Model Goodness-of-fit statistics: Chi-square $=73.03$, Degrees of freedom $=23, \chi^{2} / \mathrm{df}=3.17, \mathrm{p}$ value $=0.000, \mathrm{GFI}=0.939$, $\mathrm{AGFI}=0.881, \mathrm{RMSR}=0.033, \mathrm{TLI}=0.973, \mathrm{CFI}=0.983, \mathrm{NFI}=0.975$ and $\mathrm{RMSEA}=0.089$

\section{MULTICOLLINEARITY ISSUES}

Before estimating the hypothesized conceptual model, multicollinearity testing among independent variables is highly recommended to identify the correlation problem among independent variables (Hair et al., 1998; Tabachnick and Fidell, 2001). The correlation values between constructs exceeding 0.90 can be indicative of multicollinearity (Hair et al., 1995). The assessment of multicollinearity can be conducted through examining the tolerance value, variance inflation factor (VIF) and condition index (Hair et al., 1998). The tolerance value is the amount of variability of the selected independent variable not explained by the other independent variables while VIF is tolerance's inverse. The cut-off points for tolerance value and VIF are 0.10 and 10 respectively. The VIF value, the inverse of $\left(1-\mathrm{R}^{2}\right)$, should be close to 1.00 , which indicates little or no multicolinearity and a cutoff value of 10.00 is considered as an acceptable VIF. Thus, a small for tolerance and a large VIF are indicative of multicolinearity. Lastly, multicolinearity can be identified by condition index which is a measure of the dependency of one variable on the others and represents the collinearity of combinations of variables in the data set. Hair et al. (1998) suggested that a condition index threshold of 30 for a given dimension, coupled with at least two variance proportions for an individual variable greater than 0.50 , is the criterion for multicollinearity. According to the correlation matrix (Table 2), all correlations between the independent variables were well below 0.90, indicating low multicolinearity problem. Both tolerance values (0.32-0.62) and VIF (1.60-2.94) from the multiple regression analysis were in the acceptable threshold. In addition, only two variance proportions for individual variables were 
more than 0.50 at the condition index at 31.73 whereas all measures were lower than 30 in the analysis. The results show that multicollinearity is negligible in this study.

To verify discriminant validity between constructs, AVE should be greater than the squared correlation between a construct and other constructs in the model. Therefore, the square root of the AVE was presented at the diagonal of the correlation matrix (shown in Table 2) for the purpose of comparing with the correlation coefficient between constructs (Green et al., 1995). Adequate discriminant validity was evident, because the diagonal elements are greater than the off-diagonal elements in the corresponding rows and columns.

Table 2: Intercorrelations Among Refined Measures and Average Variance Extracted

\begin{tabular}{|c|c|c|c|c|c|c|c|c|}
\hline & Y1 & Y2 & X1 & $\mathbf{X 2}$ & X3 & $\mathrm{X} 4$ & X5 & $\mathrm{X6}$ \\
\hline Attitudinal Loyalty (Y1) & .88 & & & & & & & \\
\hline Behavioral Loyalty (Y2) & $.83 * *$ & .88 & & & & & & \\
\hline Informational Complexity (X1) & $.45^{* *}$ & $.31 * *$ & .87 & & & & & \\
\hline Position Involvement (X2) & $.69 * *$ & $.61 * *$ & $.61 * *$ & .87 & & & & \\
\hline Volitional choice (X3) & $.49 * *$ & $.43 * *$ & $.53^{* *}$ & $.57 * *$ & .81 & & & \\
\hline Brand Affect (X4) & $.63 * *$ & $.54 * *$ & $.38 * *$ & $.61 * *$ & $.40 * *$ & .90 & & \\
\hline Brand Trust (X5) & $.55 * *$ & $.46^{* *}$ & $.44 * *$ & $.57 * *$ & $.39 * *$ & $.80 * *$ & .85 & \\
\hline Uncertainty Avoidance (X6) & $.47 * *$ & $.30 * *$ & $.42 * *$ & $.46^{* *}$ & $.14 * *$ & $.46^{* *}$ & $.44 * *$ & .84 \\
\hline
\end{tabular}

Note: ** Correlation is significant at the 0.01level (1-tailed), **Significant at $\mathrm{p}<.01$

*Correlation is significant at the 0.05 level (1-tailed), *Significant at $\mathrm{p}<.05$

Diagonal is square root of average variance extracted

\section{RECURSIVE PATH ANALYSIS: EMPIRICAL TESTING OF HYPOTHESIZED MODEL}

After having satisfied the requirements arising from the measurement model, a test of structural relationships using AMOS version 4.01 was conducted to assess the data-model fit and the hypothesized relationships between theoretical constructs. The structural model achieved an overall good fit. The chisquare/degrees of freedom ratio was within the recommended level of 2.00 to $3.00\left(\chi^{2} / \mathrm{df}=2.97\right)$, indicating an acceptable fit, and all goodness-of-fit indices were in the desirable ranges. Though the chi square goodness of fit was significant $\left(\chi^{2}=672.23, \mathrm{df}=226, \mathrm{p}<0.000\right)$, all measures of fit for the structural model indicate sound fit statistics: goodness-of-fit index $(\mathrm{GFI})=0.829$, adjusted goodness-of-fit index $(\mathrm{AGFI})=0.773$, root mean square residual $(\mathrm{RMR})=0.232$, Tucker-Lewis index $(\mathrm{TLI})=0.918$, comparative fit index $(\mathrm{CFI})=0.933$, normed fit index $(\mathrm{NFI})=0.903$, and root mean square error of approximation $($ RMSEA $)=0.085)$. The structural model output displayed in Table 3 shows that the model explained a substantial portion of the variance in all the endogenous variables; attitudinal loyalty $50 \%$ and behavioral loyalty $54 \%$.

Table 3: Summary of Hypotheses Testing Results

\begin{tabular}{cllccc}
\hline H: & \multicolumn{1}{c}{ From } & \multicolumn{1}{c}{ To } & $\begin{array}{c}\text { Standardized } \\
\text { estimate }\end{array}$ & t-values & Supported \\
\hline H1a & Informational complexity & Attitudinal loyalty & -0.219 & -1.557 & No \\
H1b & Informational complexity & Behavioral loyalty & 0.304 & 2.731 & Yes** \\
H2a & Position involvement & Attitudinal loyalty & 0.420 & 4.175 & Yes*** \\
H2b & Position involvement & Behavioral loyalty & 0.326 & 3.448 & Yes*** \\
H3a & Volitional choice & Attitudinal loyalty & -0.152 & -1.602 & No \\
H3b & Volitional choice & Behavioral loyalty & 0.251 & 1.926 & Yes* \\
H4a & Brand affect & Attitudinal loyalty & 0.317 & 3.293 & Yes*** \\
H4b & Brand affect & Behavioral loyalty & 0.253 & 2.350 & Yes** \\
H5a & Brand trust & Attitudinal loyalty & 0.020 & 0.862 & No \\
H5b & Brand trust & Behavioral loyalty & 0.221 & 1.960 & Yes* \\
\hline Square & Attitudinal loyalty: 0.50 and Behavioral loyalty: 0.54 & &
\end{tabular}

Squared multiple correlations for Attitudinal loyalty: 0.50 and Behavioral loyalty: 0.54

Model Goodness-of-fit statistics: Chi-square $=672.23$, Degrees of freedom $=226, \chi^{2} / \mathrm{df}=2.97, \mathrm{p}$ value $=0.000$, GFI $=$ $0.829, \mathrm{AGFI}=0.773, \mathrm{RMSR}=0.232, \mathrm{TLI}=0.918, \mathrm{CFI}=0.933, \mathrm{NFI}=0.903$ and $\mathrm{RMSEA}=0.085$

Note: $* \mathrm{p}=0.05, * * \mathrm{p}=0.01, * * * \mathrm{p}=0.001$

Based on one-tailed t-tests: t-value $>1.65, \mathrm{p}<0.05$ : t-value $>2.33, \mathrm{p}<0.01$, and t-values $>3.09, \mathrm{p}<0.001$ 


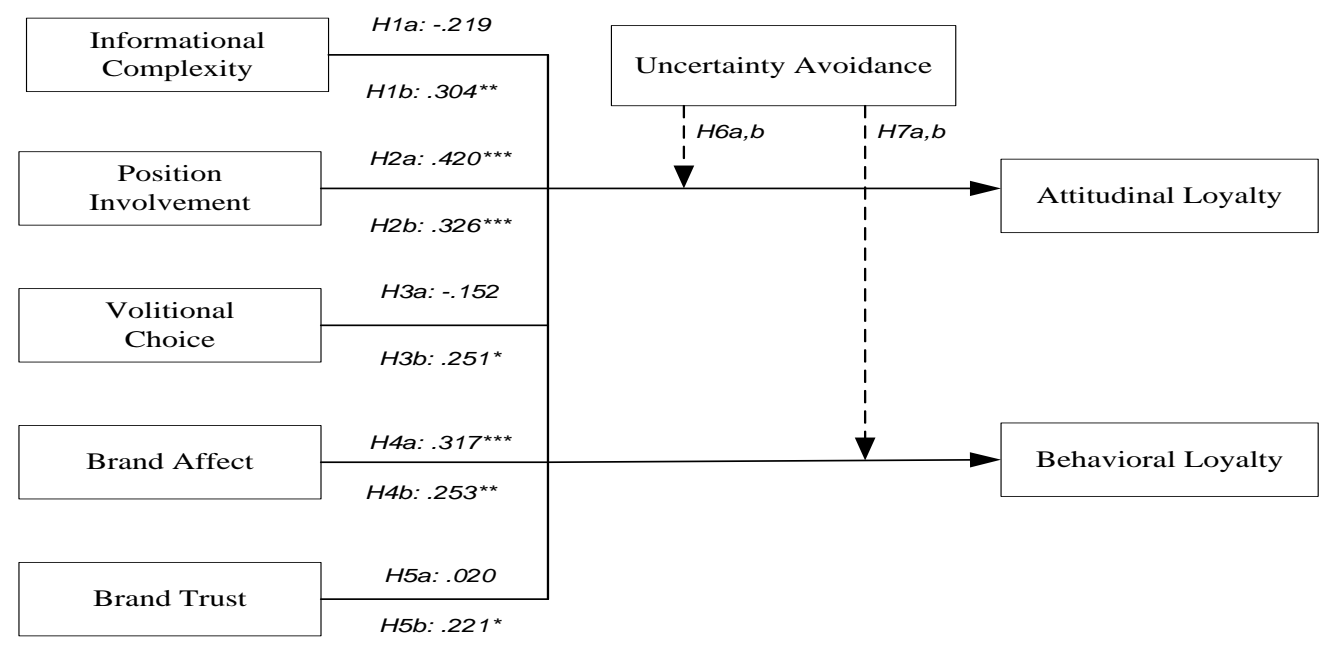

Figure 1: Conceptual Model

The hypothesis testing was accomplished by examining the completely standardized parameter estimates and their associated t-values. One-tailed tests of significance were used to determine the significance of each path coefficient. In general, estimates were consistent with expectation because all hypothesized relationships were significant $(\mathrm{p}<0.001, \mathrm{p}<0.01$ and $\mathrm{p}<0.05)$ and in the expected direction, with the exception of the relationship between informational complexity, volitional choice, brand trust and attitudinal loyalty. In sum, position involvement was found to be the most powerful predictor of attitudinal loyalty $(\beta=0.420)$ and behavioral loyalty $(\beta$ $=0.326$ ). The final structural equation model, shown in Table 3, indicated support for three hypothesized paths in the theoretical model at the significant level of 0.001 ( $\mathrm{t}>3.09$ ), two hypothesized paths at the significant level of 0.01 ( $\mathrm{t}>2.33$ ) and two hypothesized paths at the significant level of $0.05(\mathrm{t}>1.65)$. The standardized path coefficients along with its associated t-values were displayed in Table 3.

\section{MODERATING TESTS OF UNCERTAINTY AVOIDANCE}

The model specification required a test of the moderating influence of uncertainty avoidance on the relationship between brand affect, brand trust and loyalty constructs. To test the moderating effect, a multi-group path analysis was employed (Bagozzi and Yi, 1989). The multi-group path analysis is a technique especially appropriate when the covariance matrices differ significantly across treatments (Voss et al., 1998). It also enables a simultaneous estimation of all hypothesized relationships across groups. This approach also allows for restricted models with systematic constraints on posited relationships. These restricted models can be evaluated for their fit to data on the basis of a chi-square statistic, non-normed fit index (NNFI) or Tucker-Lewis index (TLI), comparative fit index (CFI), and other indicators, including the root mean square error of approximation (RMSEA) (Marsh et al., 1996).

Additional analysis was conducted to examine differences between the high and low uncertainty avoidance groups. These differences were tested using a split-group analysis procedure (high versus low on the moderating variable) (Osterhus, 1997). The sample of 474 individuals was divided into two groups on the basis of the degree of uncertainty avoidance by using high versus low median splits on the uncertainty avoidance variables. The moderating effect of uncertainty avoidance was tested and observed the relative change in model fit (Osterhus, 1997).

To assess the commonalities and differences between low and high uncertainty avoidance groups, two alternative multiple sample models were estimated. First, a unconstrained model having no constraints across 
samples on the structural parameters was estimated. Then, a constrained model was estimated, in which the four relationships that were constrained to be equal across two samples. A significant interaction effect exists if the change in the chi-square value is significant. For the high versus low uncertainty avoidance groups, the unconstrained model provided a Chi Square value of 1044.34 (d.f. $=452, \mathrm{p}<0.000$ ). Note that the Chi Square value and degrees of freedom are equal to the respective sums for the structural models estimated separately for the two samples. The model with equality constrains on the two common relationships provided a chi square value of 1056.11 (d.f. $=459, \mathrm{p}<0.000$ ). Of most interest here, though, was the rejection of the hypotheses that these two relationships were invariant across the two samples $\left(\Delta \chi^{2}{ }_{7}=11.77, \mathrm{p}<0.05\right)$. According to the Table of critical value of Chi-Square, critical value at the alpha of 0.05 (confidence level of 95\%) and degree of freedom of 7 is 14.07 (14.07 > 11.77). Thus the difference is statistically insignificant at a less than 0.05 which suggests that uncertainty avoidance has no moderating impact on the previously hypothesized relationships.

\section{DISCUSSION AND CONCLUSION}

The research findings supported the significant direct relationships between three dimensions of commitment and attitudinal and behavioral loyalty. No support was found for the hypothesized relationships between informational complexity and attitudinal loyalty and between volitional choice and attitudinal loyalty. These finding are partly consistent with previous study of Iwasaki and Havitz (2004) who suggested that resistance to change fully mediated the effects of commitment's formative factors on loyalty. As hypothesized, brand affect contributes to predicting both attitudinal and behavioral loyalty; while brand trust influences solely on behavioral loyalty. These findings are consistent with Chaudhuri and Holbrook (2002) who supported the direct link between brand affect, brand trust and loyalty. Contrary to expectations, no support is found for the moderating effect of uncertainty avoidance on the relationships between brand affect and brand trust and loyalty constructs.

\section{MANAGERIAL IMPLICATION}

Based on the research findings, marketing practitioners are recommended to strengthen customer loyalty by maximizing position involvement, the most powerful indicator of attitudinal and behavioral loyalty. Such strategies emphasize maximizing customers' commitment by the extent to which they identify with important values and selfimages associated with the preference. Moreover, marketers may consider strategies focusing on disseminating organizational knowledge to customers with an aim to move them closer intellectually and emotionally to the organization (Gruen, et.al, 2000). Regarding brand affect, the emotional bonds between airlines and customers should be taken into account in order to build customer loyalty.

\section{ACKNOWLEDGEMENTS}

The authors wish to thank The Thailand Research Fund for sponsoring this research.

\section{REFERENCES}

1. $\quad$ Aaker, D.A. 1991, Managing brand equity. The Free Press: New York.

2. Aaker, D. A. 1996, 'Measuring brand equity across products and markets.' California Management Review, 38(Spring), pp.102-20.

3. Assael, Henry. 1998, Consumer behavior and marketing action. Cincinnati, OH: South-Western.

4. Backman, S.J., \& Crompton, J.L. 1991, 'The usefulness of selected variables for predicting activity loyalty', Journal of Leisure Science, vol. 13, pp. 205-220.

5. Bagozzi, R.P., \& Yi, Y. 1988, 'On the use of structural equation models in experimental designs', Journal of Marketing Research, vol. 26, August, pp. 271-284.

6. Bei, L. T. and Y. C. Chiao, 2001, 'An integrated model for the effects of perceived product, perceived service quality, and perceived price fairness on consumer satisfaction and loyalty', Journal of Consumer Satisfaction, Dissatisfaction and Complaining Behavior, vol.14, pp. 125-140.

7. $\quad$ Berry, L. L. 1996, 'Retailers with a future.' Marketing Management, 5(Spring), pp. 39-46.

8. Bollen, K.A. 1989, Structural equations with latent variables. New York: Wiley. 
9. Cacares, R.C. and Paparoidamis, G.N. 2007, 'Service quality, relationship satisfaction, trust, commitment and business-to business loyalty', European Journal of Marketing, vol. 41, 7/8, pp. 836-867.

10. Chaudhuri, A. and M. B. Holbrook. 2001, 'The chain of effects from brand trust and brand affect to brand performance: The role of brand loyalty.' Journal of Marketing 65(2), pp. 81-93.

11. Chaudhuri, A. and M. B. Holbrook. 2002, 'Product-class effects on brand commitment and Brand outcomes: The role of brand trust and brand affect.' Journal of Brand Management, 10(1), pp.33-58.

12. Chow, S. and R. Holden. 1997, 'Toward an understanding of loyalty: The moderating role of trust.' Journal of Management Issues, 9(3), pp.275-298.

13. Day, G.S. 1969, 'A two-dimensional concept of brand loyalty', Journal of Advertising Research, vol. 9.

14. Delgado, E., J. L. Munuera, et al. 2003, 'Development and validation of a brand trust scale.' International Journal of Market Research, 45(1), pp.35-54.

15. Dick, A., \& Basu, K. 1994, 'Customer loyalty: toward an integrated conceptual framework', Journal of the Academy of Marketing Science, vol. 22, no. 2, pp. 99-113.

16. Doney, P. M. and J. P. Cannon. 1997, 'An examination of the nature of trust in buyer-seller relationships' Journal of Marketing, 61(2), pp.35-51.

17. Fornell, C., \& Larcker, D.F. 1981, 'Evaluating structural equation models with unobservable variables and measurement error', Journal of Marketing Research, vol. 18, pp. 39-50.

18. Freedman, L.L. 1964, 'Involvement, discrepancy and change', Journal of Abnormal and Social Psychology, 69, pp.290-295.

19. Garbarino, E., \& Johnson, M.K. 1999, 'The different roles of satisfaction, trust and commitment in customer relationships, Journal of Marketing, vol. 63, April, pp. 70-87.

20. Green, D.H., Barclay, D.W., \& Ryans, A.B. 1995, 'Entry strategy and long-term performance: conceptualization and empirical examination', Journal of Marketing, vol. 59, October, pp. 1-16.

21. Gundlach, G. T., R. S. Achrol, et al. 1995, 'The structure of commitment in exchange.' Journal of Marketing,_59(January), pp.78-92.

22. Hair, J.F., Anderson, R.E., Tatham, R.L., \& Black, W.C. 1995, Multivariate data analysis with readings. $4^{\text {th }}$ ed., Upper Saddle River, NJ: Prentice-Hall.

23. Hair, J.F., Anderson, R.E., Tatham, R.L., \& Black, W.C. 1998, Multivariate data analysis. $5^{\text {th }}$ ed, Upper a. Saddle River, NJ: Prentice-Hall.

24. Hennig-Thurau, T., Gwinner, K., \& Gremler, D. 2002, 'Understanding relationship marketing outcomes'. Journal of Service Research, vol. 4, no. 3, pp. 230-247.

25. Hofstede, G. 1991, Cultures and Organizations: Software of the Mind. New York, NY: McGraw - Hill

26. Iwasaki, Y. and Havitz E. M. 2004, 'Examining relationships between leisure involvement, psychological commitment and loyalty to a recreation agency', Journal of Leisure Research, vol. 36, iss. 1, pg. 45, 28 pgs.

27. Jago, L.K., \& Shaw, R.N. 1998, 'Special events: a conceptual and definitional framework', Festival Management and Event Tourism, vol. 5, no. 1, pp. 21-32.

28. Jones, T.O., \& Sasser, E.W. 1995, 'Why satisfied customers defect', Journal of Harvard Business Review, November/December, pp. 88-99.

29. Marsh, H., Balla, J., \& Hau, K. 1996, 'A valuation of incremental fit Indices: a clarification of mathematical and Empirical properties’. in Advanced Structural Modeling: Issues and Techniques. Marcoulides, G, \& Schumacker, R. (Eds.) Mahwah, NJ: Lawrence Associates, pp. 315-345.

30. Moorman, Christine; Gerald Zaltman and Rohit Deshpande. 1992, 'Relationships between providers and users of market research: The dynamics of trust within and between organizations', Journal of Marketing Research, 29 (August), pp.314-328.

31. Morgan, R.M., \& Hunt, S.D. 1994, 'The commitment-trust theory of relationship marketing', Journal of Marketing, vol. 58, July, pp. 20-38.

32. Nunnally, J.C. 1978, Psychometric theory. New York: McGraw-Hill.

33. Oliver, R.L. 1992, 'An investigation of the attribute basis of emotion and related affects in consumption: suggestions for a stage-specific satisfaction framework', in Advance in Consumer Research, vol. 19, Sherry, J., \& Sternthal, B. (Eds.) Provo, UT: Association for Consumer Research, Forthcoming.

34. Oliver, R.L. 1999, 'Whence consumer loyalty?', Journal of Marketing, vol. 63, pp. 33-44.

35. Oppermann, M. 1999, 'Whence consumer loyalty', Journal of Marketing, vol. 63, Special issue, pp. 33-44.

36. Oppermann, M. 2000, 'Tourism destination loyalty', Journal of Travel Research, vol. 39, no. 1, pp. 78-84. 
37. Park, C. S. and V. Srinivasan. 1994, 'A survey-based method for measuring and understanding brand equity and its extendibility.' Journal of Marketing Research,_31(May), pp.271-88.

38. Pritchard, M., Howard D.R. and Havitz M. 1992, 'Loyal measurement: A critical examination and theoretical extension', Leisure Science, 14, pp.155-164.

39. Pritchard, M., Havitz, M., \& Howard, D. 1999, 'Analyzing the commitment loyalty link in service contexts', Journal of Academy of Marketing Science, vol. 27, no. 3, pp. 333-348.

40. Reicheld, F., \& Sasser, W. 1990, 'Zero defections: quality comes into services', Journal of Harvard Business Review, September-October, pp. 105-111.

41. Reichheld, F. 1996, The Loyalty Effect: The Hidden Force Behind Growth, Profits and Lasting Value. Boston, MA: Harvard Business School Press.

42. Reichheld, Federick and Phil Schefter. 2000, 'E-Loyalty: Your Secret Weapon on the Web', Harvard Business Review, 78 (July/August), pp.105-113.

43. Reid, L.J., \& Reid, S.D. 1993, 'Communicating tourism suppliers: service building repeat visitor relationships', Journal of Travels and Tourism Marketing, vol. 2, no. 2/3, pp. 3-20.

44. Ringberg, T. and S. F. Gupta. 2003, 'The importance of understanding the symbolic world of customers in asymmetric business-to-business relationships.' The Journal of Business \& Industrial Marketing, 18(6/7), pp.607-626.

45. Samuelsen, B.M. and K. Sandvick. 1997, 'The concept of customer loyalty', in proceedings: Marketing: Progress, Prospects, Perspectives, EMAC Conference, 20-23 May, Warwick Business School, pp.11221140.

46. Sharma, N. and P. G. Patterson. 1999, 'The impact of communication effectiveness and service quality on relationship commitment in consumer, professional services' The Journal of Services Marketing, 13(2), pp.151-170.

47. Sirdeshmukh D., Jagdip, S., \& Barry, S. 2002, 'Consumer trust, value, and loyalty in relational exchanges', Journal of Marketing, vol. 66, pp. 15-37.

48. Tabachnick, B.G., \& Fidell, L.S. 2001, Using multivariate statistics. $4^{\text {th }}$ ed, New York: HarperCollins.Tourism Authority of Thailand, viewed 20 June 2005, <http://www.tat.or.th> vol. 78, July/August, pp. $105-113$.

49. Tax, S., S. Brown, et al. 1998, 'Customer evaluations of service complaint experiences: Implications for relationship marketing’ Journal of Marketing, 60(April), pp.60-76.

50. Uncles, M.D. and Gilles Laurent. 1997, 'Editorial: Special issue on loyalty', International Journal of Research in Marketing, 14 (5), pp.399-404.

51. Urban, G. L., F. Sultan, et al. 2000, 'Placing trust at the center of your internet strategy' Sloan Management Review, 42(Fall), pp.39-49.

52. Voss, G.B., Parasuraman, A., \& Grewal, D. 1998, 'The roles of price, performance, and expectations in determining satisfaction in service exchanges', Journal of Marketing, vol. 62, October, pp. 441-476.

53. Waterson, M. 2003, 'The role of consumers in competition and competition policy', International Journal of Industrial Organisation, Vol.21, No. 2, pp.129-150.

54. Zeithmal, V.A., Berry, L.L., \& Parasuraman A. 1996, 'Problems and strategies in services marketing', Journal of Marketing, vol. 60, April, pp. 31-46.

55. Zeithaml, V. A, Leonard L. Berry and A. Parasuraman. 1996, 'The behavioural consequences of service quality' Journal of Marketing, April, 60, pp.31-46. 
NOTES 